\title{
Penerapan RFID Dalam Pendataan Kehadiran Pegawai Negeri Sipil Berbasis Arduino
}

\author{
Andreas Aman Tokan*, Iskandar Fitri, Rini Nuraini \\ Fakultas Teknologi Komunikasi Dan Informatoika, Teknik Informatika, Universitas Nasional, Jakarta, Indonesia \\ Email: 1, ${ }^{*}$ andretokan17@gmail.com, ${ }^{2}$ tektel2001@yahoo.com, ${ }^{3}$ rini.nuraini@ civitas.unas.ac.id \\ Email Penulis Korespondensi: andretokan17@gmail.com
}

\begin{abstract}
Abstrak-Era modern saat ini, perkembangan teknologi dan informatika sudah bukan hal yang asing bagi kalangan masyarakat. Seperti saat ini teknologi RFID dan Microsoft Excel dapat digunakan untuk mengatasi masalah dalam kehidupana sehari-hari seperti presensi siswa atau pegawai pada instansi swasta maupun milik pemerintah, security system, parking system, serta dapat dimanfaatkan untuk memonitoring berbagai laporan tentang inventory yang dapat diketaui secara real time baik dengan cara online ataupun sinkronasi data, dengan begitu perkembangan teknologi RFID ini sudah tidak dapat diragukan lagi. Akan tetapi perkembangan teknologi di Indonesia sendiri belum sepenuhnya merata dimana terdapat beberapa daerah yang masih belum menerpkan teknologi ini sebagai alat bantu kegiatan sehari-hari, masih banya sekali daerah yang melakukan pendaatan kehadiran pegawainya masih menggunakan metode para ataupun tanda tangan hal ini tentu saja dapat menimbulkan kecurangan yang dilakukan oleh oknum pegawai untuk suatu kepentingan pribadi. Tujuan dari penelitian ini adalah untuk mengoptimalkan dan mengurangi manipulasi absensi para pegawai kantor camat, dikarenakan masih banyak sekali instasi pemerintahan khususnya instansi pemerintahan daerah yang masih melakukan absensi secara manual seperti kantor kecamatan Witihama. Kecamatan Witihama merupakan salah satu kecamatan di Indonesia timur tepatnya berada di Kabupaten Flores Timur, Nusa Tenggara Timur yang masih menggunakan metode paraf pegawai, maka dibutuhkan sebuah teknologi seperti RFID ini untuk menunjang kerja para pegawai karena teknologi ini sangatlah efektif. Fungsi dari penggunaan RFID yaitu untuk memvalidasi absensi serta fungsi dari Microsoft Excel sendiri adalah media informasi dan sistem monitoring absensi secara langsung dan akurat oleh komisi disiplin kantor camat.
\end{abstract}

Kata Kunci: RFID; Excel; Absensi; Arduino; Pegawai

\begin{abstract}
In today's modern era, the development of technology and informatics is not something foreign to the public. As currently, RFID and Microsoft Excel technology can be used to overcome problems in everyday life such as student attendance or employees in private and government-owned agencies, security systems, parking systems, and can be used to monitor various reports on inventory that can be known in real time. time either by online or by synchronizing data, so the development of RFID technology cannot be doubted. However, the development of technology in Indonesia itself has not been fully evenly distributed where there are some areas that still do not apply this technology as a tool for daily activities, there are still a lot of regions that collect employee attendance still use the para or signature method, this of course can lead to fraud committed by unscrupulous employees for personal gain. The purpose of this study is to optimize and reduce attendance manipulation of subdistrict office employees, because there are still a lot of government agencies, especially local government agencies that still perform attendance manually, such as the Witihama sub-district office. Witihama District is one of the sub-districts in eastern Indonesia, precisely in East Flores Regency, East Nusa Tenggara which still uses the employee initials method, so a technology such as RFID is needed to support the work of employees because this technology is very effective. The function of using RFID is to validate attendance and the function of Microsoft Excel itself is a media of information and attendance monitoring system directly and accurately by the disciplinary commission of the sub-district office.
\end{abstract}

Keywords: RFID; Excel; Attendance; Arduino; Employee

\section{PENDAHULUAN}

Kantor camat Witihama merupakan sebuah kecamatan yang teletak di Indonesia bagian timur lebih tepatnya berada di kabupaten Flores Timur provinsi Nusa Tenggara Timur. Dikecamatan ini masih menerapkan absensi dengan cara manual untuk pegawai kecamatan, proses ini dapat dimanipulasi oleh para pegawai kantor camat sehingga tidak dapat dipantau secara langsung oleh komisi disiplin/badan pengawas kantor camat. Tujuan dari absensi yaitu untuk mengetahui absensi seseorang baik itu pegawai instansi pemerintahan maupun swasta dalam menjalankan tugasnya, absensi juga merupakan sutau bentuk kegiatan dalam upaya membangun Sumber Daya Manusia (SDM).

Pada dasarnya sistem absensi dalam sebuah instasi berbeda-beda, ada yang menggunakan metode manual ataupun dengan menggunakan bantuan teknologi seperti Id card ataupun fingerprint. namun masih banyak instansi swasta atau pemerintahan yang menggunakan sistem manual, seperti tanda tangan atau paraf, tentu dengan menggunakan sistem seperti ini sangatlah rawan untuk disalahgunakan oleh oknum yang tidak bertanggung jawab.

Untuk mengantisipasi tindakan yang tidak bertanggung jawab tersebut maka diperlukan sebuah teknologi seperti Radio Frequency Identification (RFID) dan Microsoft Excel guna menunjang absensi kehadiran pegawai kantor camat serta meningkatkan kualitas sumber daya dan pelayanan publik.

Pemanfaatan Radio Frequency Identification atau biasa disingkat RFID yaitu sebuah sistem otomatis menangkap data nirkabel [1]. Teknologi ini sudah dikembangkan sebagai salah satu teknologi yang dapat mempermudahkan manusia dalam melakukan validasi atau berbagai hal, yang terdiri tag yaitu berupa chip khusus yang mempunyai kode informasi unik dan satu reader yang dapat membaca kode-kode pada Tag tersebut [2]. RFID dapat mengkombinasikan keunggulan yang tidak terdapat pada teknologi lain yaitu menyediakan perangkat 
yang hanya di baca saja (Read Only) atau dapat juga dibaca dan ditulis (Read/Writer)[3]. Saat ini sudah sangat banyak seperti scaning barcode untuk supermakert. kartu akses untuk para pegawai kantor, serta digunakan untuk melakukan perjalan menggunakan kereta api.

Selain manfaat RFID begitu banyak saat ini banyak sekali operator ataupun koperasi-koperasi daerah yang menggunakan software Micrososft Excel sebagai alat bantu untuk memberikan informasi data secara praktis dan terperinci serta efesien. Microsoft Excel sendiri merupakan sebuah spreadsheet yang canggih untuk menjalankan berbagai formula. Spreadsheet yaitu lembar kerja Excel yang berupa kolom dan baris. Dan mudah untuk dioperasikan [4].Sebuah jurnal dengan judul "Pemanfaatan Microsoft Excel Untuk Pembelajaran Matematika Dan Grafik” juga mengatakan bahwa aplikasi Microsoft Excel adalah salah satu software bagian dari Microsoft Office yang biasa digunakan untuk mengatasi permasalahan yang berkaitan dengan dunia pemodelan matematika [5]. Pada penelitian terdahulu dengan judul "Sistem monitoring Absensi Perkuliahan Dengan mennggunakan RFID Berbasis Respberry P $i$ " dengan menggunakan teknologi Respberry Pi B+ sebagai pencatat absensi mahasiswa [6]. Dan sebuah penelitian lain dengan judul "Rancang Bangun Sistem Absensi Karyawan Menggunakan RFID Yang Terintegeritas Dengan Database Berbasis Web pada CV Fokus Abadi"[3],Serta penelitian lainnya dengan judul "Perancangan Dan Implementasi Sistem Absensi Cerdas Berbasis Arduino Uno Mega" dengan menerapkan RFID sebagai media verifikasi untuk absensi karyawan [12]

Dari beberapa penelitian terdahulu yang telah dilakukan, dengan itu penulis melakukan sebuah pengembangan sistem dengan memanfaatkan Microsoft Excel sebagai media informasi absensi pegawai, hal ini di karena Microsoft Excel sangat mudah di operasikan serta dapat menyimpan hasil absensi dengan 2 (dua) mode yaitu secara online dan offline (Dekstop Aplication). Penyimpanan dengan metode online yaitu dengan memanfaatkan fitur Onedrive yang telah disediakan oleh Microsoft hal ini untuk mengantisipasi hal diluar dugaan seperti keruskan pada komponen komputer admin, dengan begitu admin dengan mudah melakukan back-up data absensi pegawai.

\section{METODOLOGI PENELITIAN}

Dalam metode penelitian yang dipergunakan dalam penerepan penerapan RFID dalam pendataan kehadiran pegawai negeri sipil berbasis arduino yaitu sebagai berikut :

\subsection{Analisis Kebutuhan Sistem}

Proses ini dilakukan dengan pengumpulan data dengan melakukan observasi pada sebuah instansi swasta maupun pemerintahan

a) Perangakat Keras Yang Dibutuhkan Untuk Membangun Sebuah System.

1. Radio-Frequncy Identification (RFID)

Seiring dengan kemajuan teknologi segala aktivitas ataupun kebutuhan bisa didapatkan dengan mudah, salah satunya adalah teknologi Radio-Frequncy Identification (RFID) teknologi ini dirancang dengan guna menidentifikasi suatu objek dengan memanfaatkan gelombang radio[7], teknologi ini secara umum membutuhkan 2 untuk berkomunikasi, yaitu Tag dan Reader [8]. Tag adalah sebuah chip yang melekat pada suatu objek yang akan diidentifikasi oleh Reader, sedangkan reader akan menangkap sinyal yang diberikan oleh Tag [9]pada saat pemindaian data, untuk dapat melakukan identifikasi dibutuhkan sebuah module RFID$R C 522$ setiap RFID tag memmiliki kode unik yang berbeda sehingga tidak ada RFID yang memilik angka identifikasi yang sama[10]. RFID dapat didefinisikan sebagai perangkat elektronik wireles yang menggunakan gelombang radio sebagai media komunikasi untuk melakukan pengidentifikasian [11].

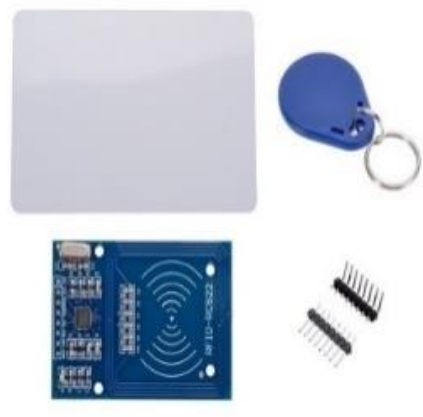

Gambar 1. Module RFID

2. Arduino Uno

Arduino Uno adalah sebuah chip mikrokontroller yang open source berbasis Atmega328, mikrokontroller ini mempunyai 14 pin input dari output digital diantaranya 6 pin input dapat digunakan sebagai output dari PWM dan 6 pin input analog. Uno sendiri berbeda dengan kebanyakan board sebelumnya yang memakai fitur ATmega 8u2 yang telah diprogram sebagai converter USB to serial. Berbeda dengan board sebelumnya yang memakai chip FTDI driver USB-to-serial. 


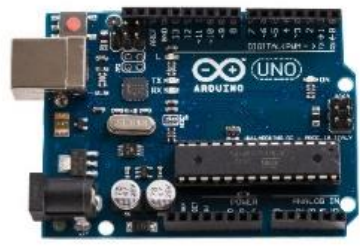

Gambar 2. Board Aduino Uno Atmega 328

b) Perangakat Lunak Yang Digunakan Untuk Membangun Sebuah System.

1. Arduino IDE (Integrated Development Environment)

Arduino merupakan sebuah software yang biasa digunakan untuk memporgram arduino Uno. Arduino IDE (Integrated Development Environment) adalah sebuah piranti lunak yang sebagai media dalam melakukan pemrograman yang bersifat open source Arduino. Arduino IDE sendiri adalah sebauh software pengembang yang telah dirancang menggunakan bahasa pemrograman tingkat tinggi yaitu JAVA, dengan dilengkapi pula library bahasa $\mathrm{C \#}$ dan $\mathrm{C}++$, penulisan dalam arduino IDE disebut dengan sketch, yaitu penulisan teks editor dan akan disimpan dalam file dengam esktensi Ino. processing arduino juga bisa digunakan dalam mengembangkan objek interaktif dan dapat dihubungan dengan berabagai software perangkat lunak [13].

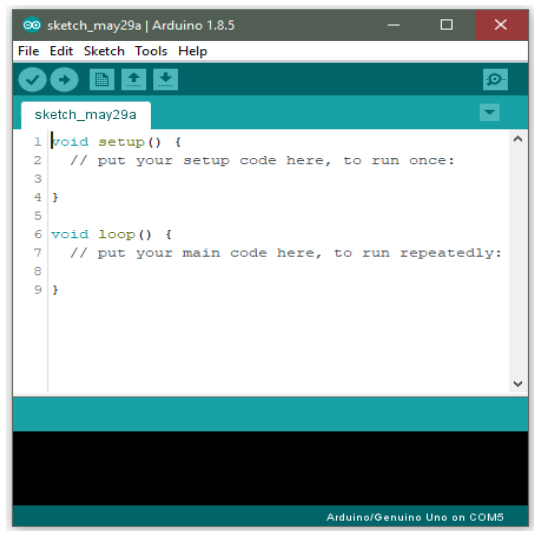

Gambar 3. Tampilan Sketch (teks editor) Arduino IDE

2. Microsoft Excel

Seiring dengan perkembangan teknologi saat ini banyak sekali pemanfaatan aplikasi Microsoft Excel yang dimanfaatkan untuk wadah komunikasi dan menjadi media informasi . Microsoft Excel merupakan salah satu program aplikasi spreadsheet (lembar kerja elektonik) pengolah data dibawah naungan Microsoft Office selain berfungsi untuk mengolah data angka, excel juga dapat digunakan untuk perhitungan kalkulasi yang sangat kompleks, baik dalam bentuk teks, grafik hingga waktu dan tanggal serta dapat dikombinasikan dengan beberapa program seperti Arduino IDE [14].

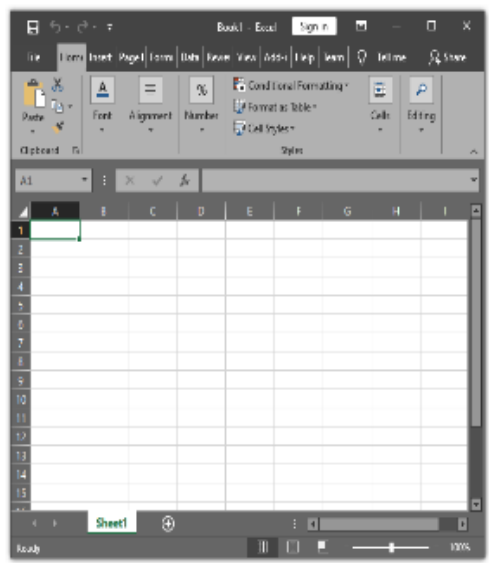

Gambar 4. Tampilan WorkSheet Microsoft Excel.

\subsection{Circuit Perangkat Keras}

Circuit Perangkat ini adalah desain rancangan perangkat keras arduino guna mempermudahkan pemrogram pada arduino IDE serta mengantisipasi terjadi kesalahan pada saat menghubungkan perangkat pada project board 
ISSN 2614-5278 (media cetak), ISSN 2548-8368 (media online)

Available Online at https://ejurnal.stmik-budidarma.ac.id/index.php/mib DOI 10.30865/mib.v5i3.3056

sehingga tidak menyebabkan terjadinya korsleting pada perangkat yang mengakibatkan perangkat rusak atau terbakar.

\subsection{Pengujian Perangkat}

Pada tahap ini bertujuan untuk mengetahui berapa lama waktu RFID Reader membaca RFID Tag. Serta jarak maksimal antar RFID Raeder untuk membaca RFID Tag. Dan lamanya waktu yang diperlukan LCDi2c untuk menampilkan output serta Buzzer $5 v$ untuk mengluarkan suara Beep Ketika RFID Reader tidak mengenali RFID Tag.

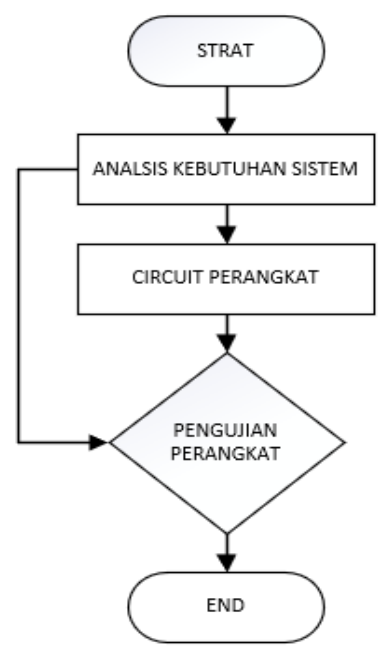

Gambar 5. Alur Tahapan Penelitian

\section{HASIL DAN PEMBAHASAN}

\subsection{FlowCharts}

FLowchart adalah deskripsi atau sebuah penggambaran alur program secara detail dengan menngunakan simbol sebagai penggambaran metode dengan menghubungkan metode lainnya. untuk mengawali tahapan sebuah penelitian maka diperlukan sebuah rancangan sistem serta menentukan komponen yang di perlukan untuk merancang prototype perangkat keras. pada gambar 6 dibawah merupakan sebuah alur program I/O pada Absensi Pegawai Negeri Sipil (PNS).

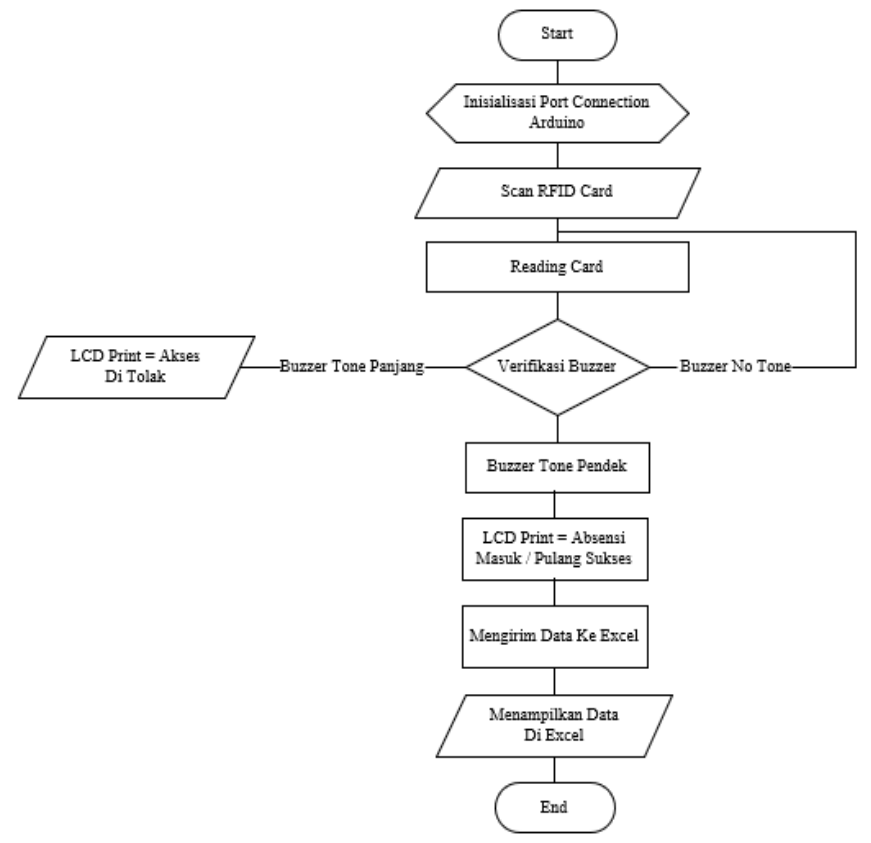

Gambar 6. Diagram Flowchart Absensi Pegawai 
ISSN 2614-5278 (media cetak), ISSN 2548-8368 (media online)

Available Online at https://ejurnal.stmik-budidarma.ac.id/index.php/mib DOI 10.30865/mib.v5i3.3056

\subsection{Circuit dan Implementasi Komponen Perangkat Keras}

Pada gambar 7 di bawah merupakan Circuit (Rangkaian) komponen dari sistem absensi dimana setiap komponen mempunyai tugasnya masing-masing, beberapa komponen yang digunakan selain RFID-RC522 dan Arduino Atmega 328p Mikrokontroller adalah : Buzzer 5v, LCD $20 x 4$ i2c, RTC (Real Time Clock), Kabel Jumper, USB Type B, Serta Papan Brodboard atau Papan Project 400 PIN.

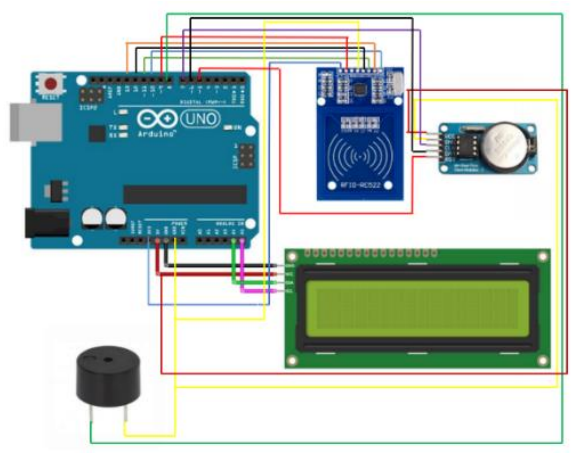

Gambar 7. Circuit Komponen Sistem Absensi

Tabel 1. Nama komponen dan fungsi dari setiap komponen

\begin{tabular}{ll}
\hline Nama Komponen & Fungsi \\
\hline Arduino Atmega 328p & Sebagai kontroller I/O data \\
LCD 20x4 i2c & Untuk menampilkan output untuk user \\
RTC (Real Time-Clock) & $\begin{array}{l}\text { Penghitung waktu dan tanggal serta menjadi timekeeper (penjaga waktu) } \\
\text { secara realtime }\end{array}$ \\
RFID - RC522 & Sebagai scan objek dan menyimpan dan mengirim informasi data ke Arduino \\
& uno \\
USB Type B & Menghubungkan Arduino Atmega 328p ke komputer \\
Papan Board & Sebagai media penghubung Arduino dengan komponen \\
Buzzer & Sebagai alarm notifikasi saat RFID tag di identifikasi oleh rader \\
\hline
\end{tabular}

Arduino Uno Atmega 328p yang berfungsi sebagai penerima data dari RFID (Radio-Frequncy Identification). Serta mengirimnya ke buzzer dan LCD 20x4 i2c sebagai output verifikasinya, setelah terverifikasi maka data tersebut akan dikirimkan ke Excel sebagai data final. Selain itu fungsi dari RTC (Real Time Clock) sebagai timekeeper (penjaga waktu) secara real time. RTC (Real Time Clock) juga dapat di definisikan sebagai sebuah jam digital yang berupa chip menggunakan jalur data parallel yang dapat menyimpan data berupa waktu, tanggal, bulan, hari serta tahun [15]. Untuk lebih jelasnya dapat dilihat pada implementasi yang di tunjukan pada gambar 8. yang telah di rangkai dan di program dengan arduino IDE.

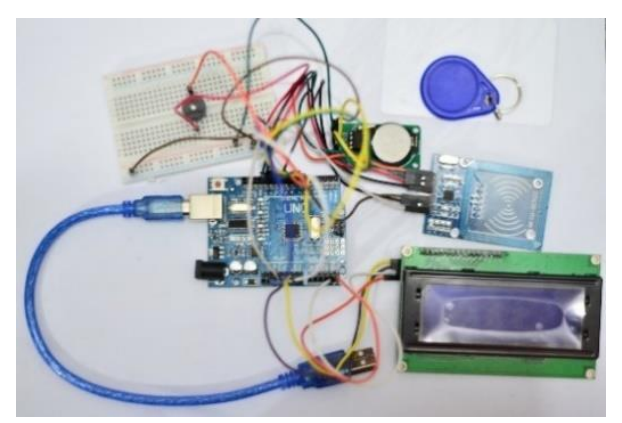

Gambar 8. Rangkaian Sistem Absensi

\subsection{Hasil Prototype Alat}

\section{a. Output Berhasil}

LCDi2c menampilkan hasil output berupa informasi check in dan check out kepada user ketika RFID Tag berhasil identifikasi oleh Reader serta diikuti oleh bunyii Beep pendek yang di hasilkan oleh Buzzer 5v dengan imterval waktu 2-3 detik, hal ini menandakan bahwa user telah berhasil melakukan absensi masuk ataupun keluar seperti yang di tunjukan pada gambar 9 di bawah ini. 
ISSN 2614-5278 (media cetak), ISSN 2548-8368 (media online)

Available Online at https://ejurnal.stmik-budidarma.ac.id/index.php/mib DOI 10.30865/mib.v5i3.3056
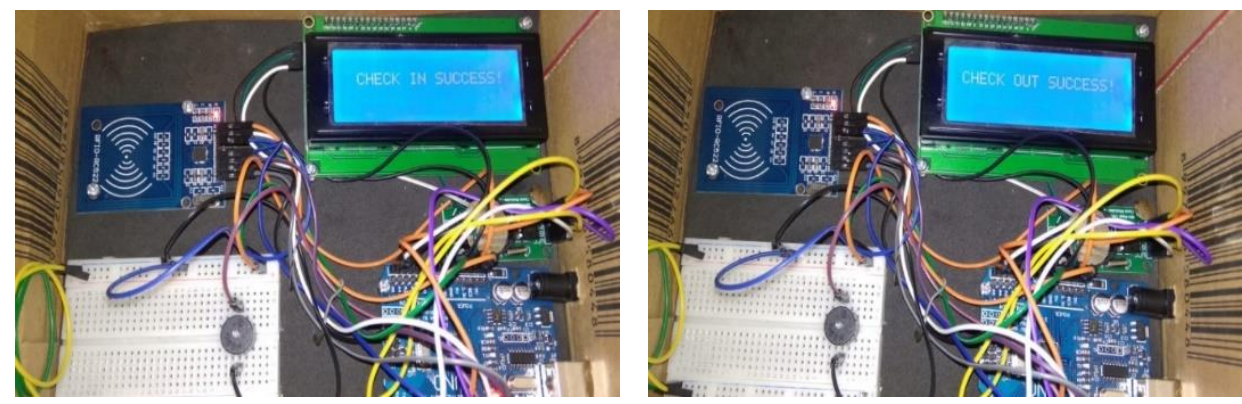

Gambar 9. Output Check In dan Check Out sukses

\section{Output Error}

Saat tidak terdidentifikasi oleh Reader maka buzzer $5 v$ akan mengelurkan beep Panjang dengan interval waktu 57 detik serta LCDi2c menampilkan informasi kepada user bahawa id nya tidak terdaftar atau tidak dikenali oleh system dapat dilihat pada gambar 10 di bawah ini

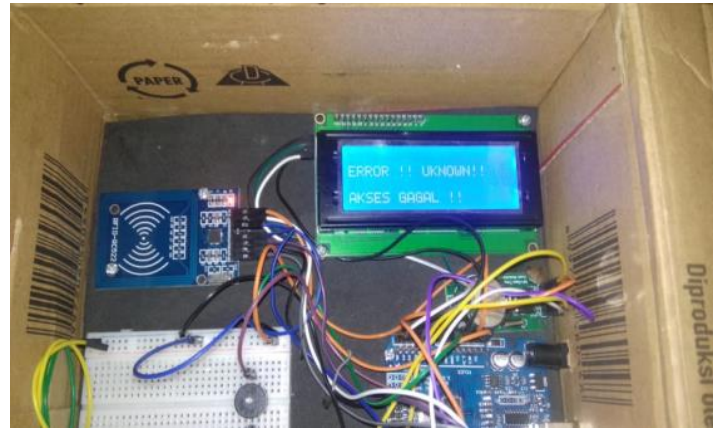

Gambar 10. Output Error pada LCD 20x4 i2c.

\section{Output RTC}

RTC adalah salah perangkat yang di gunakan untuk menghitung algoritma dan memberikan informasi terkait yaitu sebagai penghitung waktu, dan tanggal serta menyimpan dan mengirim informasi data waktu dan tanggal secara raeltime[17] yang akan ditampilkan pada LCDi2c dapat dilihat pada gambar 11, guna memberikan iformasi waktu kepada para pegawai pada saat melakukan scan Tag pada Reader.

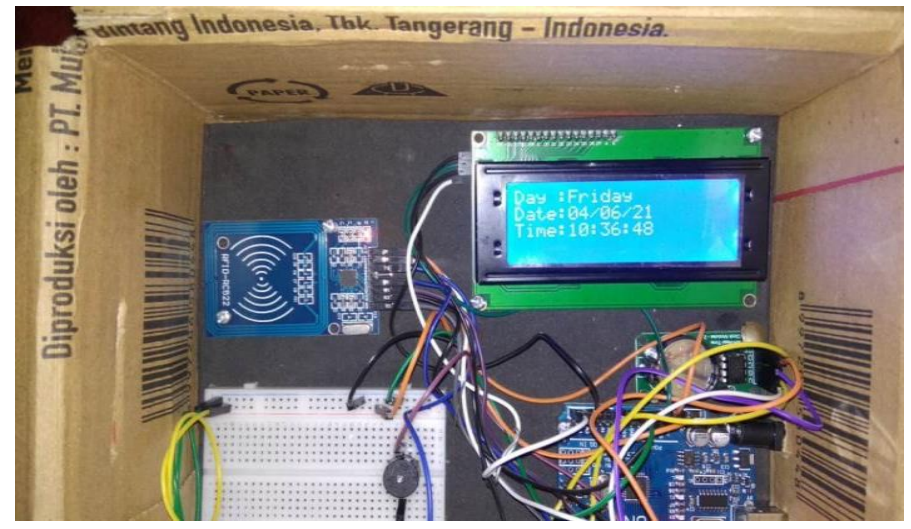

Gambar 11. Output RTC Module pada LCD 20x4 i2c

\section{Output Pada Ms.Excel}

Informasi mengenai absensi yang valid akan di tampilkan di Microsoft Excel dan OneDrive, dengan begitu informasi informasi tentang waktu masuk, waktu pulang serta hari dan tanggal begitu detail. Sehingga dapat dijadikan rekapitulasi ataupun laporan ketika sewaktu-waktu diperlukan. Dalam spreadsheet ini juga terdapat informasi mengenai jabatan serta NIP (Nomor Induk Pegawai) dapat dilihat pada gambar 12 \& 13 dibawah. Sehingga dapat dengan mudah mengetahui pegawai mana saja yang tidak melakukan absensi. Serta RFID Tag tidak dapat discan ulang ketika sudah mealukan scan Tag untuk absensi pulang, Ketika user melakukan hal tersebut maka buzzer akan mengeluarkan tone yang panjang serta LCD outputnya error seperti yang di tujukan pada gambar 10 di atas. 
ISSN 2614-5278 (media cetak), ISSN 2548-8368 (media online)

Available Online at https://ejurnal.stmik-budidarma.ac.id/index.php/mib DOI 10.30865/mib.v5i3.3056

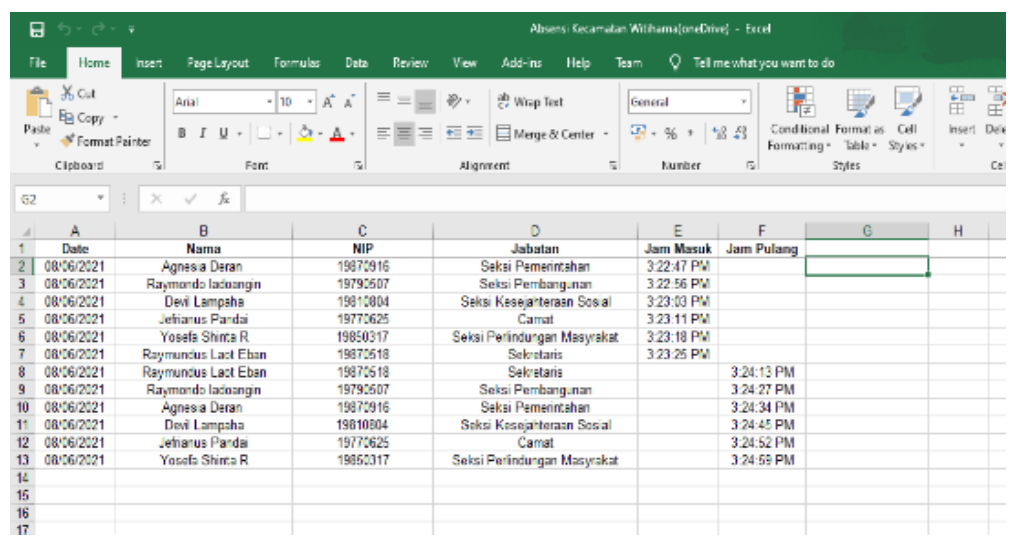

Gambar 12. Hasil Informasi Excel pada Excel Dekstop

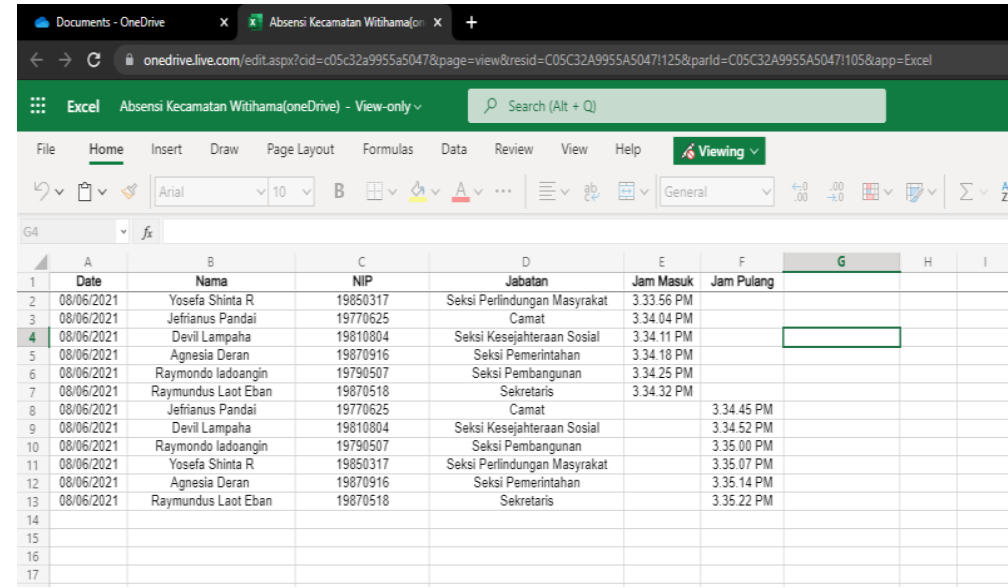

Gambar 13. Hasil Informasi Excel pada OneDrive

\subsection{Pengujian Perangkat}

Pada tabel berikut ini merupakan hasil pengujian dari perangkat RFID.

Tabel 2. Pengujian Perangkat

\begin{tabular}{|c|c|c|c|}
\hline No & Skenario Pengujian & Hasil Pengujian & Kesimpulan \\
\hline 1 & $\begin{array}{l}\text { RFID Reader mengidentifikasi } \\
\text { RFID Tag dengan cepat }\end{array}$ & $\begin{array}{l}\text { RFID Reader dapat mengidentifikasi RFID Tag dengan } \\
\text { memerlukan waktu } 1.30 \text { detik }\end{array}$ & valid \\
\hline 2 & $\begin{array}{l}\text { LCD menampilkan informasi } \\
\text { success dan error }\end{array}$ & $\begin{array}{l}\text { LCDi2c dapat menampillakn informasi success selama } \\
5 \text { detik dan informasi error sealam } 7 \text { detik }\end{array}$ & valid \\
\hline 3 & $\begin{array}{l}\text { RTC mengupdate informasi } \\
\text { waktu berupa hari, tanggl, waktu } \\
\text { dan tahun }\end{array}$ & $\begin{array}{l}\text { RTC dapat mengupdate informasi waktu berupa hari, } \\
\text { tanggl, waktu dan tahun secara real time }\end{array}$ & valid \\
\hline 4 & $\begin{array}{l}\text { Buzzer } 5 \mathrm{v} \text { mengelurkan suara } \\
\text { beep }\end{array}$ & $\begin{array}{l}\text { Buzzer dapat mengelurakn suara beep selama 1detik } \\
\text { untuk menanadakan bahwa RFID teridentifikasi serta } 7 \\
\text { detik untuk identifikasi RFID Reader tidak mengenali } \\
\text { RFID Tag }\end{array}$ & Valid \\
\hline 5 & $\begin{array}{l}\text { Ms. Excel menampilkan } \\
\text { informasi dengan cepat dan } \\
\text { dapat disimpoan sebagai backup } \\
\text { data }\end{array}$ & $\begin{array}{l}\text { Ms. Excel dapat menampilkan informasi dengan } \\
\text { memerlukan waktu } 1.30 \text { detik serta dapat di simpan } \\
\text { dengan } 2 \text { metode yaitu online dan offline }\end{array}$ & Valid \\
\hline
\end{tabular}

\section{KESIMPULAN}

Berdasarkan hasil dan analisis dari pengujian yang telah dilakukan, maka dapat disimpulan sistem pendataan kehadiran ini berjalan dengan baik, RFID Reader memerlukan waktu 1.30 detik untuk membaca RFID Tag, jarak maksimal RFID Reader membaca RFID Tag adalah 3,5 CM, Microsoft Excel memerlukan 1.40 Detik uncuk menampilkan output data, RTC (Real Time Clock) dapat mengupdate waktu baik jam, hari tanggal dan tahun 
secara otomatis. Adanya sistem Radio Frequency Identification (RFID) sebagai mesin absensi ini maka para pegawai di kecamatan Witihama dapat meningkatkan sumber daya manusia serta meningkatan pelayan kepada masyarakat. Penggunaan Microsoft Excel sebagai media informasi dan monitoring sangtatlah efektif dan efesien, hal ini dikarenakan sangat mudah saat pengoperasian dan tidak memerlukan biaya ataupun internet, hal ini disebabkan karena penyebaran internet di pelosok negeri belum juga merata dan juga belum stabil, maka diperlukan sebuah teknologi ini untuk menunjang kinerja dan kejujuran para pegawai dikecamatam, serta data absensi ini dapat di simpan untuk laporan atau rekapitulasi oleh komisi displin kecamatan.

\section{REFERENCES}

[1] Purwianto, Eka., dkk."Pemanftaan RFID (Radio Frequency Identification) Sebagai Alternatif Absensi Siswa (Studi Kasus : SMK Ar-Rahma Sukabumi, Jawa Barat)”. Jurnal Teknoinfo, Vol. 13 N0o 2, ISSN 2615-224X, 2019.

[2] Panoto, Nurhadi, "Prototype Presensi Kelas Berbasis RFID Dan Mikro SD”. Program Studi Teknik Elektro: Universitas Muhammdiyah Surakarta. Jully 2017.

[3] Ahmad, Adiyaksa W."Rancang Bangun Sistem Absensi Karyawan Menggunakan RFID Yang Terintegeritas Dengan Database Berbasis Web pada CV Fokus Abadi”. Fakultas Teknologi Dan Komunikasi : Universitas Dinamika, Agustus 2020.

[4] Andriyani, Devy. dkk. "Aplikasi Microsoft Excel Dalam Penyelesaian Masalah Rata-rata Data Berkelompok”. Ejournal unisba: Junal Matematika, Vol. 18 No. 1, ISSN: 1412-5056 / 2598-8980, Mei 2019.

[5] Harmastuti \& Styowati, Dwi,"Pemanfaatan Microsoft Excel Untuk Pembelajaran Matematika Dan Grafik". Jurnal Dharma Bakti. Vol. 1 No. 1, ISSN: 2614-2929, April 2018.

[6] Nasir, Muhammad. Dkk. "Sistem Monitoring Absensi Perkuliahan Dengan menggunakan RFID Berbasis Rapberry pi". Proceeding Seminar Nasional politeknik Negeri Lhokseumawe. Vol 3 No 1, NISSN 2598-3954, Oktober 2019

[7] Setyawan, Dedy.,S.kom,.M.M., " Sistem Absensi Karyawan RSUD Kardinah Dengan Menggunakan RFID”. Tematik : Jurnal Teknologi Informasi Dan Komunikasi. Vol 5 No 1, Juni 2018

[8] Dewanto, Murti F., dkk.”Pengembangan Sistem Informasi Absensi Berbasis Radio Frequency Identification (RFID) Terintegritas Dengan Sistem Informasi Akademik". Jurnal Informatika:Jurnal Pengembangan IT(JPIT). Vol 2, No. 02, ISSN: 2477-5126, Jully 2017.

[9] Kosasih M, Niki. dkk. "Sistem Absensi Dosen Menggunakan Radio Frequency Identification (RFID) Berbasis Web". JREC : Journal Of Electrical And Electronics. Vol. 5 No 2., Maret 2018.

[10] Hartawan, Pri, G. \& Isa, Tofik. I, “Aplikasi Absensi Perkuliahan Dengan Menggunakan Mikrokontroler Arduino Berbasis RFID”. Jurnal SANTIKA: Jurnal Ilmiah Sains Dan Teknologi, Vol 6 No 2, ISSN2088-5407, Desember 2016.

[11] Oktarina, Dwi,.M.kom, \& Halim, Jimmy.,S.Kom.,"Sistem Informasi Penjualan Dengan Menerapkan Teknologi RFID". Riau Journal Of Computer Science, vol.3 No.2. 146-155|146, Jully 2017.

[12] Suherdi, Devri, Nurmadiyah \& Aji, Sabda. "Perancangan Dan Implementasi Absensi Cerdas Berbasis Arduino Mega". J-SISKO TECH : Jurnal Teknologi Informasi dn Teknologi komputer TGD. Vol 2 No 2, ISSN : 2621-8976, Jully 2019

[13] Sokop, Jendri S. dkk., “Trainer Periferal Antarmuka Berbasis Mikrokontroler Arduino Uno". E-Journal Teknik Elektro dan Komputer, vol.5 no.3, ISSN: 2301-8402, 2016.

[14] Julaeha, Siti \& Somawati. "Sosialisasi Pengoperasian Microsoft Excel Untuk Administrasi Data Matematis Pada Karang Taruna”. Jurnal PKM: Pengabdian kepada Masyarakat, Vol. 02 No. 03, p-ISSN 2614-574X, September-Desember 2019.

[15] Misriana \& Kartika, "Alat Patroli Lingkungan Perkantoran Berbasis Radio Frequency Identification (RFId)", Proceeding Seminar Nasional Politeknik Negeri Lhokseumawe, Vol.2 No.1, ISSN: 2598-3954, September 2018.

[16] Dewanto, Murti. F., Herlambang. A. B, \& Harjantana, J. T. A., "Pengembangan Sistem Absensi Berbasis Radio Frequency Idenfication (RFID) Terintegrasi Dengan Sistem Informasi Akademik". Jurnal Informasi: Jurnal Pengembangan IT (JPIT). Vol. 02, No. 02. ISSN: 2477-5126, Jully 2017.

[17] Miubarok, Syahrul, dkk.’Pemanfaatan Modul RTC Berbasis Arduino Mega Sebagai Penentu Variabel Nutrisi Pada Sistem Kontrol Hidroponik", Jurnal Transistor Elektro dan Informatika (TRANSISTOR EI). Vol. 3, No.1, pp. 5 8, Mei 2018. 